\title{
Growth of the tropical zoanthid Palythoa caribaeorum (Cnidaria: Anthozoa) on reefs in northeastern Brazil
}

\author{
JANINE F. SILVA ${ }^{1}$, PAULA B. GOMES ${ }^{2}$, ERIKA C. SANTANA ${ }^{2}$, JOÃO M. SILVA ${ }^{2}$, \\ ÉRICA P. LIMA ${ }^{3}$, ANDRE M.M. SANTOS ${ }^{3}$ and CARLOS D. PÉREZ ${ }^{3}$ \\ ${ }^{1}$ Pós-Graduação em Biologia Animal, Universidade Federal de Pernambuco, Rua Prof. \\ Moraes Rego, 1235, Cidade Universitária, 50670-420 Recife, PE, Brasil \\ ${ }^{2}$ Universidade Federal Rural de Pernambuco, Departamento de Biologia, Rua \\ Dom Manoel de Medeiros, s/n, Dois Irmãos, 52171-900 Recife, PE, Brasil \\ ${ }^{3}$ Universidade Federal de Pernambuco, Centro Acadêmico de Vitória, Núcleo de Biologia, \\ Rua do Alto do Reservatório, s/n, Bela Vista, 55608-680 Vitória de Santo Antão, PE, Brasil \\ Manuscript received on September 16, 2014; accepted for publication on November 28, 2014
}

\begin{abstract}
In Brazilian reefs, zoanthids, especially Palythoa caribaeorum are fundamental for structuring the local benthic community. The objective of this study was to determine the growth rate of P. caribaeorum, and to assess the influence of the site (different beaches), season (dry and wet), location (intertidal or infralittoral zones), and human pressure associated with tourism. For one year we monitored the cover of $P$. caribaeorum in transects and focused on 20 colonies. We cut off a square $\left(100 \mathrm{~cm}^{2}\right)$ from the central part of the colony and monitored the bare area for four months in each season. The average growth rates varied from 0.015 and $0.021 \mathrm{~cm} \cdot$ day $^{-1}$. The rate was homogeneous in all localities, and there was no influence from colony site, location, or touristic visitation, showing that the growth velocity may be an intrinsic characteristic of the species, with a strong genetic component. The growth rate of $P$. caribaeorum differed among months, and peaked in the first month after injury. The average cover varied from 6.2 to $22.9 \%$ and was lower on the reef visited by tourists. The present study corroborates the hypothesis that $P$. caribaeorum is important for coastal reef dynamics due to its fast and continuous growth.
\end{abstract}

Key words: growth rate, trampling, tropical reefs, zoantharia.

\section{INTRODUCTION}

Coral reefs are very important due to the several ecosystem services they provide (Dight and Scherl 1997, Moberg and Folke 1999), their high productivity (Connell 1978, Birkeland 1997), their biodiversity (Moberg and Folke 1999), and their dynamism (Osborne 2000). As they occupy only

Correspondence to: Carlos Daniel Pérez

E-mail: cdperez@ufpe.br
$0.5 \%$ of sea bottoms (Moberg and Folke 1999), biological interactions, in particular competition, are essential to maintain the dynamics and the diversity of their community.

Among the biological groups that best characterize reefs in the world are anthozoan cnidarians. The species composition of this group varies geographically, but dominant species play similar ecological roles in different reefs. This is 
the case of scleractinian corals and zoanthid (Fautin 1988). Both are sessile, suspensivorous, mostly carnivorous, can bear zooxanthellae in their tissues, and play a key role in community structuring. Zoanthids form dominant groups of sessile macroinvertebrates in reefs, such as those in Jamaica (Karlson 1980), whereas scleractinians predominate in reefs in the Indo-Pacific (Fautin 1988). In addition, zoanthids may dominate sites where stress conditions lead to a decrease in scleractinian corals (Fautin 1988), such as Hawaii (Cooke 1976) and Brazil (Cruz et al. in press). Brazilian coastal reefs are covered mainly by zoanthids (Oigman-Pszczol et al. 2004, Floeter et al. 2007, Francini-Filho et al. 2013) and the dominant species is P. caribaeorum, which is common in the western Atlantic (Acosta et al. 2005, Francini-Filho et al. 2013).

The broad distribution and high cover of P. caribaeorum is probably the result of several factors, such as colony plasticity (Karlson 1983, Costa et al. 2011), physiological tolerance (Sebens 1982), mixture of sexual and asexual reproductive strategies (Fadlallah et al. 1984, Acosta and Asbahr 2000, Acosta et al. 2001), fast growth (Suchanek and Green 1981, Rabelo et al. 2013), strong competitive ability (Bastidas and Bone 1996), and antipredator mechanisms (Sebens 1982). In addition, P. caribaeorum produces palytoxin (Tubaro et al. 2011), which together with the factors mentioned above, makes this species an aggressive competitor for space in reefs (Suchanek and Green 1981, Acosta et al. 2001, Mendonça-Neto and Gama 2009).

The capacity of reproduction, survival, and substrate cover is directly related to the size of benthic organism colonies (Jackson 1977, Hughes and Cancino 1985, Garrabou 1999, Acosta et al. 2001, 2005). In P. caribaeorum the process of colony fission has been well studied, as well as the action of environmental conditions on polyp morphology, fission and fragmentation rates (Acosta et al. 1998, 2001, 2005, Acosta and Sammarco 2000, Costa et al. 2011). However, it is important to differentiate colony fission (McFadden 1986), which contributes to population size, from the fission of an individual polyp, which contributes to colony growth (Acosta et al. 2005). In this context, the influence of the environment on the colony's growth rate for $P$. caribaeorum (and zoanthids in general) is still poorly known.

Considering the high ecological importance of this species in Brazilian reefs and its competitive interactions, the objectives of the present study were to estimate the growth rate of $P$. caribaeorum in reefs in the northeastern coast of Brazil and to test whether this rate changes under different environmental conditions. The results will allow us to understand the role of this species in structuring benthic community.

\section{MATERIALS AND METHODS}

STUDY AREA

We carried out the present study in the tropical reefs at Porto de Galinhas (8॰33'00"- 8०33'33" S; $\left.35^{\circ} 00^{\prime} 27^{\prime \prime}-34^{\circ} 59^{\prime} 00^{\prime \prime} \mathrm{W}\right)$ and Suape (8'21'45"-

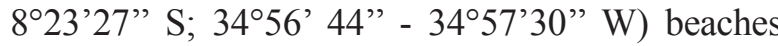
in the State of Pernambuco in northeastern Brazil (Fig. 1). The area has a warm and humid climate. Historical average annual rainfall is $2,483.6 \mathrm{~mm}$ and average annual temperature is $24.7^{\circ} \mathrm{C}$. There is little temperature variation throughout the year (from 26 to $30^{\circ} \mathrm{C}$ ), but there is a strong difference in rainfall distribution. The rainy season (March to August) concentrates over $70 \%$ of the annual rainfall. Hence, the region is characterized by two climatic seasons: dry and rainy (Medeiros et al. 1999).

The beaches have fringe reef formations, known as sandstone banks or beachrocks (Laborel 1970). Suape, located $40 \mathrm{~km}$ away from Porto de Galinhas, has a reef line with 3,500 $\mathrm{m}$ in length and $80 \mathrm{~m}$ in width, at approximately $1,200 \mathrm{~m}$ from the coastline making the access of people to the reef difficult. Conversely, the reef of Porto de Galinhas has an extension of $900 \mathrm{~m}$ and is close to the beach line, within easy access, which makes this beach one 


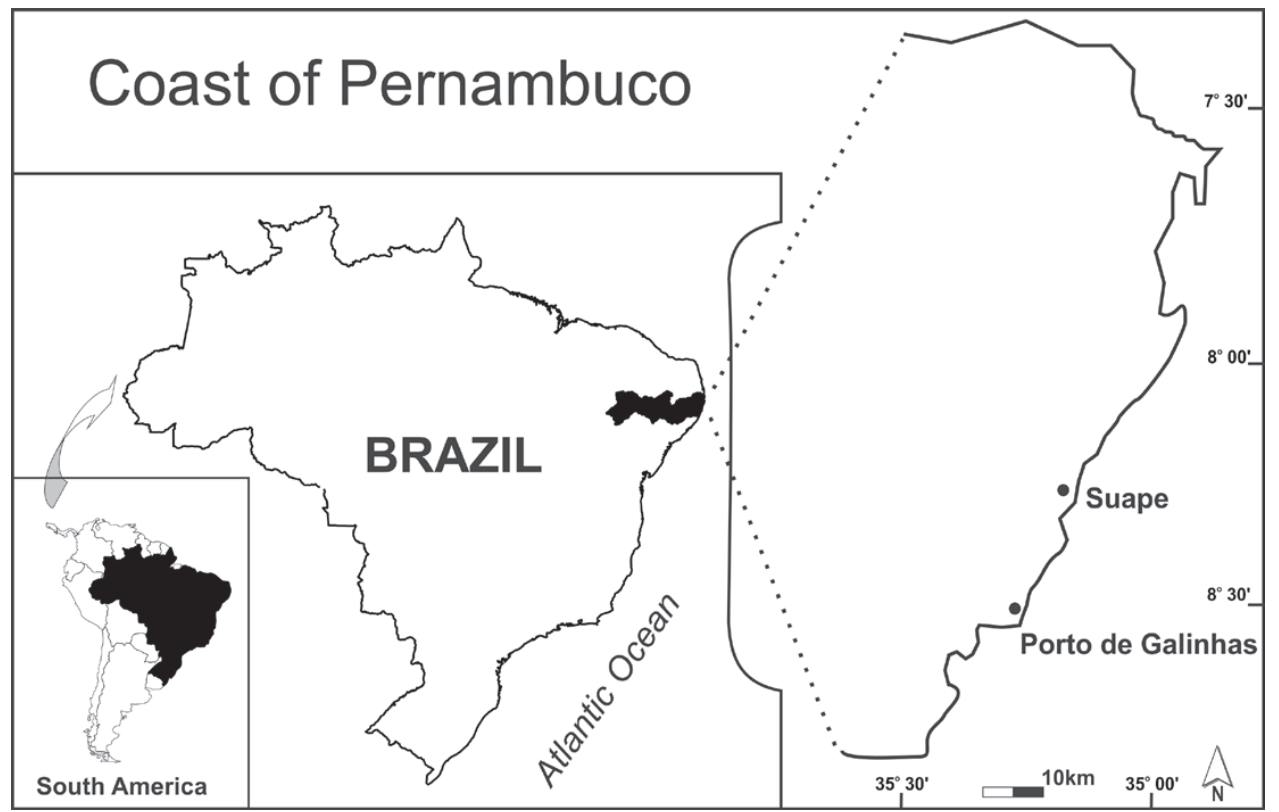

Figure 1 - Location of the Suape and Porto de Galinhas beaches along the coast of the State of Pernambuco, in northeastern Brazil.

of the most visited in the Brazilian coast. Annually, Porto de Galinhas receives approximately 65,000 tourists (Sarmento et al. 2011). The reef is divided in two sectors by a channel with approximately $8 \mathrm{~m}$ in depth. The south sector consists of an area delimited by buoys that allow visits by tourists to specific parts of the reef (visited reef). The north sector does not receive tourists, mainly due to the lack of natural pools and the strong irregularity of the reef (unvisited reef). To characterize the areas with and without tourists, on a Saturday in May, two independent observers counted the reef walkers during four periods of 10-min of observations with 20-min intervals between them.

\section{SAMPLING DESIGN}

In order to estimate the growth rate of $P$. caribaeorum, we monitored 20 colonies picked at random. It was removed a $100 \mathrm{~cm}^{2}$ square of the central region of the colony with a spatula. The objective of this experiment was to find the maximum growth rate of the colony without the interference of competitors, which would be observed close to the free edge of the colony. During the entire experiment the site was not occupied by other organisms, and, hence, scraping or removal was not necessary.

The center of the square formed by tissue removal was marked with underwater epoxy resin (TECPOX MES-500) to facilitate its location (Fig. 2). Each colony was marked with a PVC plate attached to the reef and its location was marked with a GPS. Digital images of the square area were taken monthly with a Canon Power Shot A620 camera and then analyzed in the program IMAGE J 1.6.0 to measure the area without zoanthid cover and its perimeter.

To assess the influence of seasonality on the growth of $P$. caribaeorum, we removed an area of the colony in the dry season and monitored it during four months (December 2010 to March 2011). We repeated the same procedure with other colonies starting in the rainy season and also monitored them during four months (May to August 2011). The experiments were carried out simultaneously 


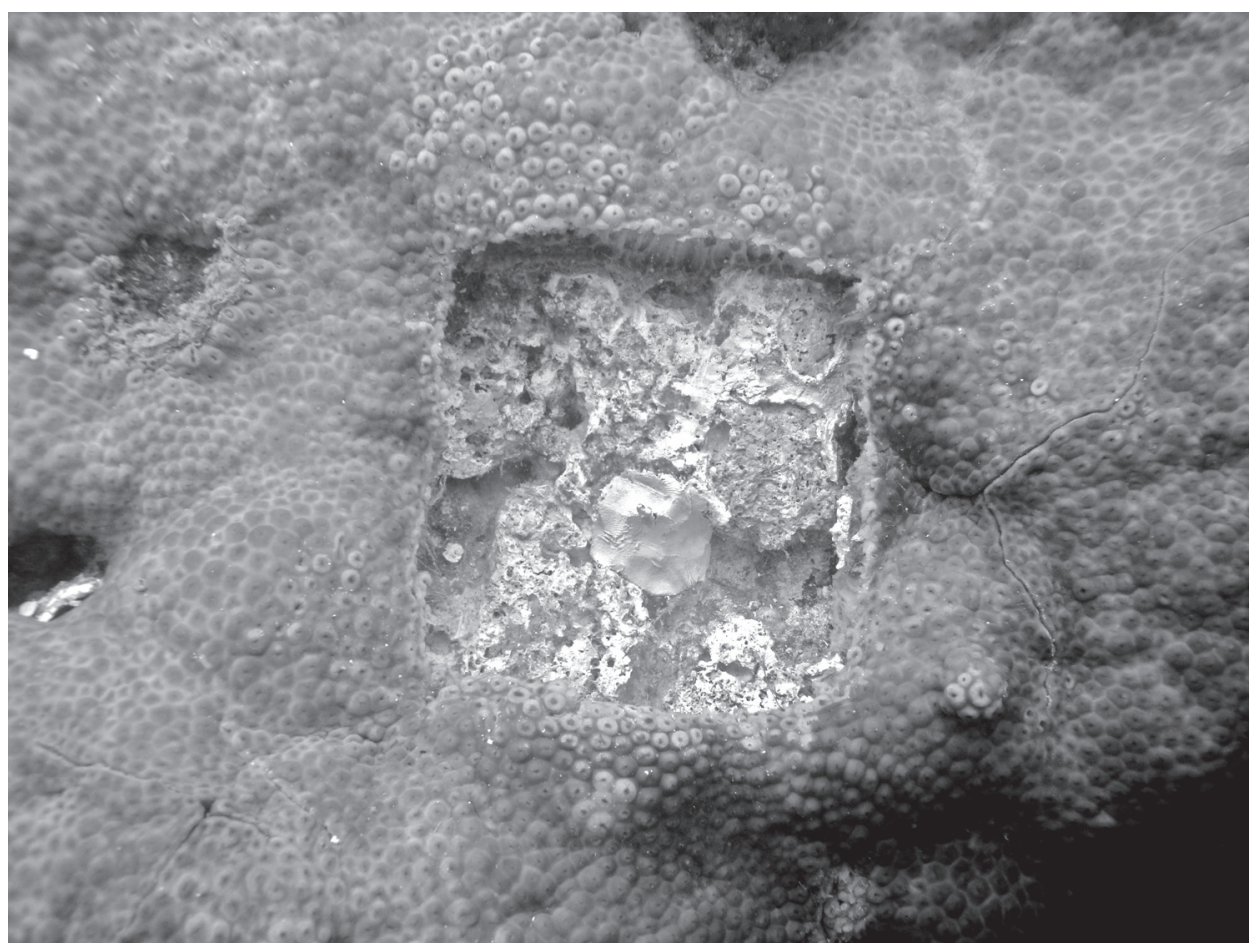

Figure 2 - Colony of Palythoa caribaeorum with an experimental area on the first day of experiment. The center of the square $\left(100 \mathrm{~cm}^{2}\right)$ formed by tissue removal was marked with underwater epoxy resin to facilitate its location.

on the beaches Porto de Galinhas (unvisited reef) and Suape, aiming at estimating the average growth rate of $P$. caribaeorum. We repeated the experiment in the area visited by tourists in Porto de Galinhas to assess the effect of humans on zoanthid growth. All the experiments were carried out in the intertidal.

In addition, to test whether stress in the intertidal (e.g., exposition to desiccation, reduction in feeding time) affected the growth of $P$. caribaeorum, we carried out the same experiment in colonies in the infralittoral of Porto de Galinhas. In this case, we monitored only 12 colonies during four months due to difficulties in marking and monitoring colonies in the infralittoral.

To calculate growth rate we considered perimeter measurements, because a previous study suggested that growth rate was affected by the size of the free edge, in which the larger the removed area (and the larger the free edge), the faster the colony growth (Bastidas and Bone 1996).
In addition, the initial bare area may vary little among colonies, and the growth rate should be based on an initial measurement (Garrabou 1999). To estimate the monthly growth rate, we used a formula modified from Garrabou (1999), in which the difference of the area between two subsequent months (growth) was divided by the perimeter of the previous month (available free edge). The value was divided by the number of days passed between measurements to obtain a daily average rate expressed in $\mathrm{cm}^{2} . \mathrm{cm}$ of edge ${ }^{-1}$.day ${ }^{-1}$, which was simplified and expressed in $\mathrm{cm} \cdot$ day $^{-1}$. Total growth rate (used in comparisons between treatments) was calculated in the same way, using the values of the first and last months of the experiment.

During the entire study (December 2010 to November 2011) the cover of $P$. caribaeorum on the reefs of Porto de Galinhas (visited and unvisited) and Suape was estimated in transects arranged perpendicularly to the beach line on the 
reefs of the intertidal. In each site, three transects were monitored each month, from the tide line on one side to the tide line on the opposite side of the reef. We estimated the cover of $P$. caribaeorum (in $\mathrm{cm})$ through the intersection of the colony with an outstretched measuring tape, following the standard method of isobathymetric lines ("transects", Loya 1972, 1978).

\section{STATISTICAL ANALYSES}

To test all hypotheses, we used generalized linear models (McCullagh and Nelder 1989) followed by post hoc Tukey tests (Hill and Lewicki 2006). The hypotheses assessed were: (a) growth rate does not differ significantly between beaches and (b) the season interferes in growth rate. In this analysis we used only the data of the unvisited reef of the intertidal of Porto de Galinhas to avoid interference from other factors in the result.

We also tested the influence of location (intertidal and infralittoral) on the growth of $P$. caribaeorum and the interaction of this factor with season. Our hypothesis was that infralittoral colonies submitted to low stress have higher growth rate than those of the intertidal, regardless of season. We used the data of the colonies of medium and infralittoral of the unvisited reef in Porto de Galinhas.

The hypothesis that tourist trampling affects colony growth in $P$. caribaeorum during dry and rainy seasons was tested by comparing the medium littoral data of visited and unvisited reefs in Porto de Galinhas.

We compared growth rate among months to test the hypothesis that in the first month of growth after injury, growth rate would be higher than any other. At first, we compared the growth rate of each month between experiments that began in dry and rainy season. As there was no difference between them $(F=0.0129 ; p=0.9102)$, the data of these two experiments were pooled. We used a generalized linear model (McCullagh and Nelder 1989) to test for differences between months and their interaction with site, and used post hoc Tukey tests (Hill and Lewicki 2006) for pairwise comparisons. For these comparisons, we used only the results obtained in the intertidal aiming at standardization.

We compared values of $P$. caribaeorum cover among months and localities. In all analyses, we previously tested for data normality and homogeneity of variances, and logarithmized the data that did not meet these assumptions. We ran the tests in the software Statistica 7.0 (StatSoft, Tulsa OK). The significance level adopted was $\alpha=0.05$.

\section{RESULTS}

The visited coral reef had an average of 156 visitors per observation interval, varying from 110 to 205 visitors, whereas the unvisited reef had an average of one visitor per observation interval, varying from 0 to 4 . Data from the City Secretariat for the Environment show that the visited reef receives no less than 5,000 tourists per month, on average, with values reaching over 15,000 in the high season according to the City Administration of Ipojuca for 2011.

During the experiment some colonies decreased their recovery area, alternating periods of growth with periods of partial mortality. The colonies that did not show total mortality continued to be monitored and those periods of decline were reflected in their final average growth rate. The colonies that showed large areas of mortality without new growth (total mortality) were excluded from the analysis. Considering all situations, out of 144 monitored colonies 59 showed partial loss in some month, and out of these, ten colonies died.

The average growth rate of $P$. caribaeorum varied from 0.015 to $0.021 \mathrm{~cm}$.day ${ }^{-1}$ (Table I). We observed no significant difference in the growth rate of $P$. caribaeorum between the beaches Porto de Galinhas and Suape or between the dry and rainy seasons, but there was an interaction between these factors (Table II, Fig. 3A). The post hoc Tukey test detected a significant difference 
between the dry and rainy seasons only in Suape ( $\mathrm{p}$ $<0.01)$. Colony site did not affect growth rate and no significant differences were detected between colonies at intertidal and infralittoral in Porto de
Galinhas. However, in a pooled analysis with mid and infralittoral data, we observed a significant difference between seasons, with higher growth rate in the dry season (Table I, Table II, Fig. 3B).

TABLE I

Samplings $(\mathrm{N})$, means and standard deviations $(\mathrm{X} \pm \mathrm{SD})$ of Palythoa caribaeorum growth rate $\left(\mathrm{cm} . \mathrm{day}^{-1}\right)$ from Porto de Galinhas and Suape beachrocks.

\begin{tabular}{l|cc|cc}
\hline & Wet & \multicolumn{2}{c}{ Dry } \\
\hline \multicolumn{1}{c|}{ Site } & $\mathbf{X} \pm$ SD & N & X \pm SD & N \\
\hline Porto de Galinhas visited & $0.015 \pm 0.010$ & 62 & $0.020 \pm 0.013$ & 55 \\
Porto de Galinhas unvisited & $0.020 \pm 0.012$ & 59 & $0.017 \pm 0.001$ & 62 \\
Porto de Galinhas infralittoral & $0.018 \pm 0.010$ & 49 & $0.015 \pm 0.008$ & 43 \\
Suape & $0.015 \pm 0.010$ & 66 & $0.021 \pm 0.011$ & 68 \\
\hline
\end{tabular}

TABLE II

GLM model results of each of the three dependent variables (Beach, Sites and Season) on the Palythoa caribaeorum growth rate. Significant results in bold. df, degrees of freedom; SS, sum of squares; MS, mean square.

\begin{tabular}{|c|c|c|c|c|c|}
\hline $\begin{array}{c}\text { Porto de Galinhas } \\
\text { unvisited x Suape and season }\end{array}$ & df & SS & MS & $F$ & $\mathrm{p}$ \\
\hline Beach & 1 & 0.000000 & 0.000000 & 0.0025 & 0.960020 \\
\hline Season & 1 & 0.000119 & 0.000119 & 0.9720 & 0.325132 \\
\hline Beach*Season & 1 & 0.001130 & 0.001130 & 9.1925 & 0.002685 \\
\hline Error & 251 & 0.030845 & 0.000123 & & \\
\hline Total & 254 & 0.032135 & & & \\
\hline $\begin{array}{l}\text { Porto de Galinhas } \\
\text { Intertidal x Infralittoral and season }\end{array}$ & df & SS & MS & $F$ & $\mathrm{p}$ \\
\hline Sites & 1 & 0.000181 & 0.000181 & 1.7141 & 0.191896 \\
\hline Season & 1 & 0.000561 & 0.000561 & 5.3057 & 0.022239 \\
\hline Sites*Season & 1 & 0.000010 & 0.000010 & 0.0941 & 0.759373 \\
\hline Error & 209 & 0.022116 & 0.000106 & & \\
\hline Total & 212 & 0.022830 & & & \\
\hline $\begin{array}{c}\text { Porto de Galinhas } \\
\text { visited } \mathrm{x} \text { unvisited and season }\end{array}$ & df & SS & MS & $F$ & $\mathrm{p}$ \\
\hline Sites & 1 & 0.000045 & 0.000045 & 0.3611 & 0.548455 \\
\hline Season & 1 & 0.000125 & 0.000125 & 1.0049 & 0.317167 \\
\hline Sites*Season & 1 & 0.001095 & 0.001095 & 8.8112 & 0.003305 \\
\hline Error & 234 & 0.029088 & 0.000124 & & \\
\hline Total & 237 & 0.030355 & & & \\
\hline $\begin{array}{c}\text { Porto de Galinhas } \\
\text { visited } \mathrm{x} \text { unvisited } \mathrm{x} \text { Suape month } \\
\text { to month }\end{array}$ & df & SS & MS & $F$ & $\mathrm{p}$ \\
\hline Sites & 2 & 0.202 & 0.101 & 0.099 & 0.905687 \\
\hline Month & 3 & 24.580 & 8.193 & 8.040 & 0.000034 \\
\hline Sites*Season & 6 & 13.995 & 2.332 & 2.289 & 0.035075 \\
\hline Error & 360 & 366.890 & 1.019 & & \\
\hline Total & 371 & 405.191 & & & \\
\hline
\end{tabular}


a

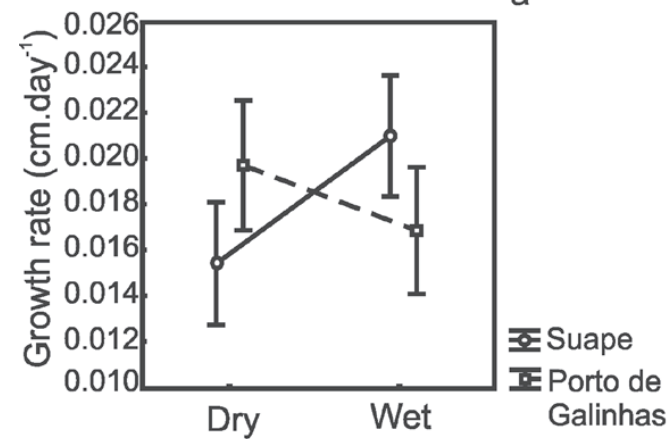

c

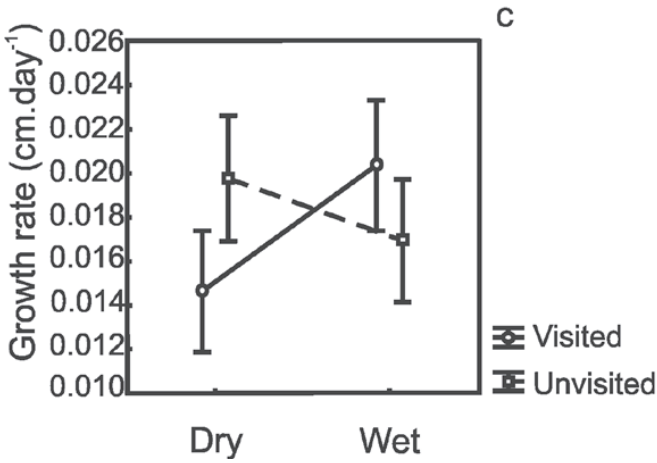

b

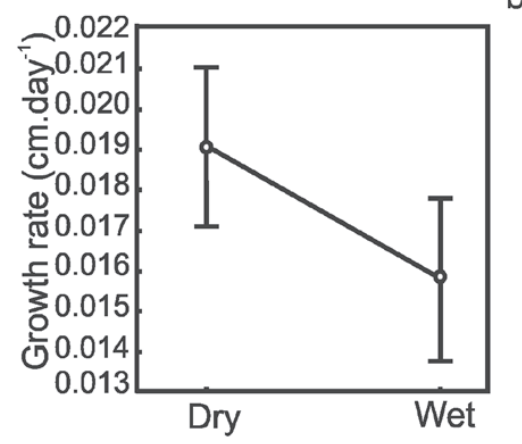

d

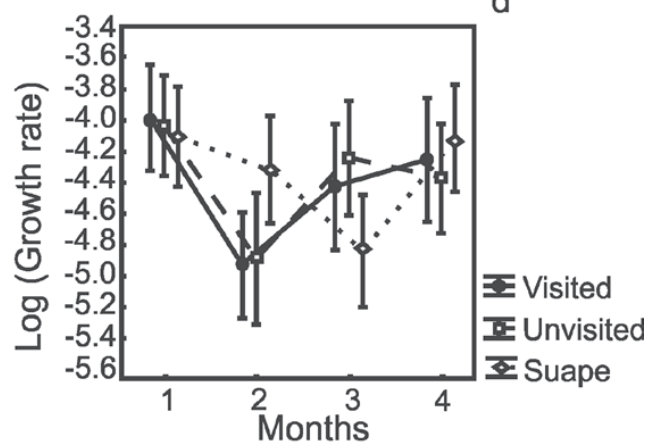

Figure 3 - Comparison of Palythoa caribaeorum growth rate $\left(\mathrm{cm} \cdot \mathrm{day}^{-1}\right)$ between a. Suape and Porto de Galinhas beaches during dry and wet seasons; b. dry and wet seasons in a pooled analysis with intertidal and infralittoral data of Porto de Galinhas beach; c. visited and unvisited Porto de Galinhas beachrocks during dry and wet seasons; d. visited and unvisited Porto de Galinhas beachrocks and Suape beach during months. Data are presented as means \pm SE. In Figure 3D, data were converted in Log +10 .

In Porto de Galinhas, in spite of no difference between visited and unvisited reefs or between dry and rainy seasons, we observed a significant interaction between factors (Table II). The Tukey test revealed that only the visited reef showed a significant difference between periods, with lower growth rates in the dry season $(\mathrm{p}<0.05)$ (Fig. 3C).

The studied colonies did not have a uniform growth in any locality. Variations in growth due to mortality were evident during the study. We found significant differences between months and there was a significant interaction between locality and month (Table II, Fig. 3D). The first month, after the removal of the tissue, showed the highest values of growth rates, followed by a decrease in the second month in all localities. After the third month, the colonies located in Porto de Galinhas (unvisited and visited reefs) resumed growing, whereas in Suape the growth rates continued to decrease and only began to rise again in the fourth month (Fig. 3D). However, pairwise comparisons revealed that within each month, growth did not differ significantly between localities. The comparison between months within each locality revealed significant differences only in the visited reef between the first and second months (Tukey test, $\mathrm{p}<0.01$ ).

The cover of $P$. caribaeorum differed between localities $(F=87.1024$; d.f. $=2 ; \mathrm{p}<0.000001$; Fig. 4): the unvisited reef in Porto de Galinhas scored $22.9 \%$, the visited reef in Porto de Galinhas scored 6.2\%, and Suape scored 9.6\%. The Tukey test revealed that the unvisited reef showed a significant difference in cover, in comparison with both the visited reef $(\mathrm{p}<$ $0.05)$ and Suape in the rainy season $(\mathrm{p}<0.05)$. 


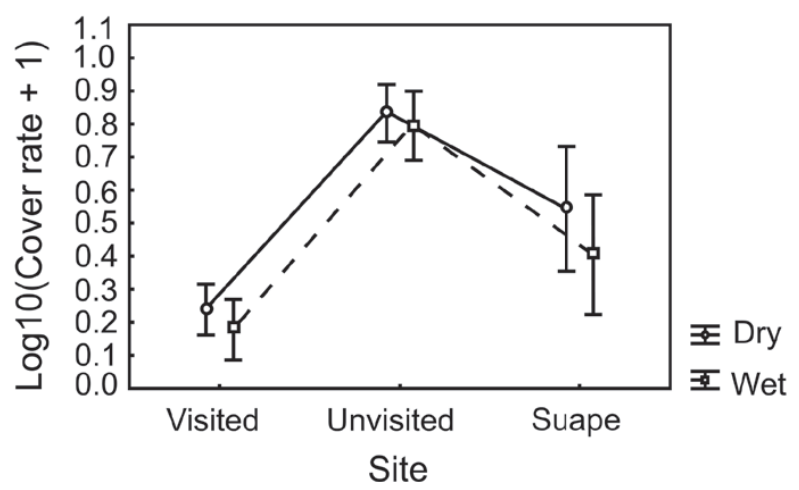

Figure 4 - Comparison of Palythoa caribaeorum cover rate $(\mathrm{cm})$ between visited and unvisited Porto de Galinhas beachrocks and Suape beach during dry and wet seasons. Data were converted in $\log 10(x+1)$.

\section{DISCUSSION}

Palythoa caribaeorum has been pointed out as the cnidarian with the highest growth rate (MendonçaNeto and Gama 2009, Costa et al. 2011), in particular considering the study by Suchanek and Green (1981). In this study the main focus was the competition between $P$. caribaeorum and other species in reefs of the Virgin Islands. The authors calculated a growth rate between 2.5 and 4 $\mathrm{mm}$.day ${ }^{-1}$ for this species. However, the experiment lasted only 20 days and the authors did not clearly state how growth measurement or rate estimation was done. In a later study, Bastidas and Bone (1996) assessed for ten months the growth rate of $P$. caribaeorum in different situations of coexistence with Zoanthus sociatus. In this other study, it is clear the way colonies were marked, the use of photographs and planimetry to calculate growth area, and the area gained by the initial perimeter is considered in the calculation of the growth rate. The authors calculated as $0.12 \mathrm{~cm}^{2}$. cm of edge $\mathrm{emonth}^{-1}$ the growth rate of $P$. caribaeorum in areas without the presence of a competitor $(100 \%$ of $P$. caribaeorum cover; competitors removed). Expressed as daily variation, the growth rate was $0.004 \mathrm{~cm}^{2}$. $\mathrm{cm}$ of edge $^{-1}$. day ${ }^{-1}$. This value is lower than that of our

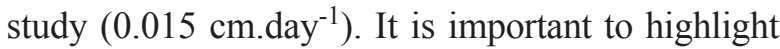

that in the estimation of the growth rate in the present study we also considered the perimeter. There is a difference in units between studies because in the present study we simplified the unit " $\mathrm{cm}^{2}$ " of the area with " $\mathrm{cm}$ " of the perimeter, which resulted in the

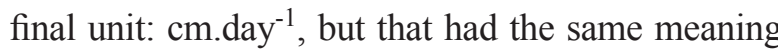
as the result by Bastidas and Bone (1996), who did not use simplified units. In both studies, the cover of $P$. caribaeorum in reefs was high, the monitoring lasted a long time and there were no competitors. The difference found in growth rate between studies may be related to the removal of a central portion of the colony in the present study. Growth rates can increase after injury (which creates an extension of free edge), and, hence, the colony removal serves as a stimulus for faster growth. Indeed, Bastidas and Bone (1996) observed that the larger the initial part removed (or edge length) from the colony, the larger the final cover of $P$. caribaeorum on the bare area, but this analysis was not made in relation to growth rate. Hence, it is possible that the results by Suchanek and Green (1981) are overestimated. Anyway, the growth rate of $P$. caribaeorum is very high and markedly superior to scleractinian species that depend on the deposition of calcium carbonate to form their skeleton (for a review of methods and data on scleractinian growth, see Buddemeier and Kinzie 1976, Buddemeier and Smith 1988). Another recently published study also found high growth rates in $P$. caribaeorum. Rabelo et al. (2013) calculated a growth rate of $11.02 \mathrm{~cm}^{2} . \mathrm{month}^{-1}$, which would result in a growth rate of $0.36 \mathrm{~cm}^{2}$.day ${ }^{-1}$. The high values found by these authors can be explained by no consideration of perimeter in the calculation of the growth rate, contrary to Bastidas and Bone (1996), and the present study. The authors simply divided the average area gained by the species during the experiment, by the number of months gone by. Hence, this value cannot be compared to the values previously cited. The great difficulty in comparing results among authors and better understanding the dynamics of processes, results from the inappropriate definition of terms and 
measures adopted or due to the lack of this information (Buddemeier and Kinzie 1976). The presentation of methods for the analysis of growth rate must be clear and there must be standardization in the calculation of growth rates, in order to allow comparisons between species and localities.

The growth rate in $P$. caribaeorum was in general very homogeneous among localities, and was not affected by colony site, location at intertidal or infralittoral, or by tourist visits. This shows that intrinsic factors regulate the growth rate of this species, and there is probably a strong genetic component.

Colonial organisms grow through somatic increase and asexual reproduction by polyp fission. Colony fission and fragmentation contribute to a local increase in population density. The genus Palythoa has a high rate of asexual reproduction (Cooke 1976). This contributes to local dispersal, colonization, gain of space in competitive interactions, and fitness increase (Acosta et al. 2001). The contribution of fission and fragmentation in population growth of zoanthids in reefs can vary among species (Acosta et al. 1998, 2001, Acosta and Sammarco 2000). In addition, fission depends on endogenous forces, which are, genetically determined, whereas fragmentation depends on exogenous forces and their rates can be affected by environmental conditions (Brazeau and Lasker 1992, Garrabou 1999, Karlson 1991). In P. caribaeorum the contribution of fragmentation is low in relation to fission (Acosta and Sammarco 2000). Fission can occur from small sizes $\left(5 \mathrm{~cm}^{2}\right.$; Acosta et al. 2005) and can be an adaptive advantage that helps increase the metabolic rate, growth, and reproduction (Ryland and Warner 1986, Stoner 1989). It also increases the colony's efficiency regarding food capture (McFadden 1986). This endogenous regulation of growth could explain the homogeneity of the growth rates found.

In spite of this homogeneity, we found differences in the growth of $P$. caribaeorum between dry and rainy seasons in some specific situations, as revealed by post hoc tests, which showed interactions between environmental factors. One example was the inverse behavior of the growth rates in Porto de Galinhas and Suape in the dry and rainy seasons. Although they had different growth rates in each season, in the end both beaches had similar average growth rates.

Some studies showed the negative effect of trampling on reef communities (Liddle and Kay 1987, Neil 1990, Hawkins and Roberts 1994, Brown and Taylor 1999, Rodgers and Cox 2003, Sarmento et al. 2011). In the present study, the growth rate of $P$. caribaeorum in Porto de Galinhas did not differ between visited and unvisited areas, not corroborating our initial hypothesis. However, in the visited reef, growth rates were significantly lower in the dry season, when tourist influx was higher, which indicates that trampling on that reef interferes negatively in colony growth in that season of the year. Nevertheless, as the visited area showed an opposite pattern in comparison to the unvisited area, these differences disappeared in the pooled analysis. This means that trampling does not affect the annual growth rate, but alters the form it occurs, which results in a different pattern.

We expected infralittoral colonies to present higher growth rate, as colonies of the intertidal need to allocate energy to avoid desiccation by producing mucus (Sebens 1982) and the low tide periods reduce their feeding time. However, $P$. caribaeorum colonies had similar growth rates in both environments, which shows that this species is well adapted to both. Actually, P. caribaeorum can enter a dormancy state, with starvation and keeping the colony covered by mucus (Acosta et al. 2005). In addition, the species is well adapted to sedimentation in the infralittoral, as it can incorporate particles of fine sediments in its tissues, at a proportion of up to 65\% (Haywick and Mueller 1997).

Under all conditions analyzed, the growth rate of $P$. caribaeorum showed high variability, which was evidenced by high standard deviations. It is 
possible that factors that were not assessed in the present study, such as interspecific competition, food availability, and predation, contribute to this variation (Ayling 1983, Hughes and Jackson 1985, Turon and Becerro 1992). The growth rate of $P$. caribaeorum varied throughout months. It was highest in the first month, which corroborates Bastidas and Bone (1996) and Rabelo et al. (2013), who recorded higher growth rates soon after injury.

The $P$. caribaeorum cover recorded in Pernambuco was similar to that observed in other localities, such as Florida Keys (18.6 19\%, Mueller and Haywick 1995), Virgin Islands (10.2 - 16.6\%, Suchanek and Green 1981), and Colombia (16.7 - 19\%; S. Gleibs, unpublished data). Other reefs in northeastern Brazil (Barradas et al. 2010, Francini-Filho et al. 2013) and rocky shores in southeastern Brazil (Castro et al. 1999, Oigman-Pszczol et al. 2004) also showed similar results. Differences between localities and periods show high dynamism of the species, which alternates periods of growth and mortality, or even bear both processes in the same colony (JFS, personal observation). This can be interpreted as a continuous search for microhabitats favorable to growth (Garrabou 1999). When Hughes and Jackson (1980) studied the growth of the coral Agaricia agaricites, they noticed that the mortality pattern was related to colony size. Small colonies died completely or remained undamaged, whereas large colonies had partial death that could result in the formation of two or three colonies by fission. This process seems very common in $P$. caribaeorum (Acosta et al. 2005) and could explain a higher cover of the species on the unvisited reef, where the colonies are larger (personal observation). Colony size can influence both mortality (Tanner 1999) and growth rate (Bastidas and Bone 1996). Trampling affects this dynamics, leading to lower cover of the species caused by higher mortality, as we evidenced no difference in growth rate between visited and unvisited areas.
The present study corroborated the hypothesis that $P$. caribaeorum is an important species for the dynamics of coastal reefs due to its fast and continuous growth and production of toxic substances (Bastidas and Bone 1996, Tubaro et al. 2011). P. caribaeorum engages in several competitive interactions in the reefs of Pernambuco, in particular with macroalgae and the zoanthids Protopalythoa variabilis and Zoanthus sociatus, but keeps its abundance high.

\section{ACKNOWLEDGMENTS}

The authors would like to thank the members of the GPA group (Grupo de Pesquisa em Antozoários) of the Universidade Federal Rural de Pernambuco and the Universidade Federal de Pernambuco who participated in the fieldwork at Porto de Galinhas and Suape, and the "jangadeiros" boatmen at those beaches. Fundação de Apoio a Ciência e Tecnologia do Estado de Pernambuco (FACEPE) awarded a Master's fellowship to J.F.Silva. This work was financed by the FACEPE (APQ-0796-2.05/10) and the Conselho Nacional de Desenvolvimento Científico e Tecnológico (CNPq) (Edital/Chamada: Portugal - CNPq/FCT, 490642/2010-1 and Edital Universal processo 480478/2008-2).

\section{RESUMO}

Nos recifes brasileiros os zoantídeos, especialmente Palythoa caribaeorum, são fundamentais na estruturação da comunidade bentônica local. O objetivo deste estudo foi determinar a taxa de crescimento de $P$. caribaeorum e avaliar a influência do local (praias diferentes), do período do ano (seco ou chuvoso), posição (médio ou infralitoral) e pressão antrópica associada ao turismo. Durante um ano acompanhamos a cobertura de $P$. caribaeorum com uso de transectos e focamos em 20 colônias. Nós retiramos um quadrado $\left(100 \mathrm{~cm}^{2}\right)$ da porção central da colônia e monitoramos a área desnuda por quatro meses em cada estação. As taxas médias de crescimento variaram entre 0,015 e $0,021 \mathrm{~cm} \cdot \mathrm{dia}^{-1}$. A taxa foi homogênea em todas as localidades, e não 
houve influência do local, posição e nem da visitação turística, mostrando que a velocidade de crescimento pode ser uma característica intrínseca da espécie, com forte componente genético. A taxa de crescimento de P. caribaeorum diferiu entre os meses, com pico no primeiro mês após a injúria. A cobertura média variou de 6,2 a $22,9 \%$ e foi menor no recife visitado por turistas. O presente estudo corrobora a hipótese que $P$. caribaeorum é importante na dinâmica de recifes costeiros devido a seu rápido e contínuo crescimento.

Palavras-chave: taxa de crescimento, pisoteio, recifes tropicais, zoantharia.

\section{REFERENCES}

Acosta A AND AsBahr M. 2000. Reproductive effort in Palythoa caribaeorum. In: Coral Reef Symposium, 8, Balboa. Proceeding of the $8^{\text {th }}$ International Coral Reef Symposium, Balboa, p. 295.

Acosta A, Duarte LF And SAmmarco PW. 1998. The role of asexual reproduction in the population dynamics of Palythoa caribaeorum (Cnidaria, Zoanthidea). In: XIII Marine Biology Symposium, São Sebastião, p. 8.

Acosta A AND SAmmarco PW. 2000. Modes of asexual reproduction in the zoanthid Palythoa caribaeorum. In: Coral Reef Symposium, 9, Bali. Proceeding of the $9^{\text {th }}$ International Coral Reef Symposium, Bali, p. 144.

Acosta A, SAmmarco PW AND DuARTE LF. 2001. Asexual reproduction in a zoanthid by fragmentation: the role of exogenous factors. B Mar Sci 68: 363-381.

Acosta A, Sammarco PW And Duarte LF. 2005. New fission processes in the zoanthid Palythoa caribaeorum: description and quantitative aspects. B Mar Sci 76: 1-26.

AYLING AL. 1983. Growth and regeneration rates in thinly encrusting Demospongiae from temperate waters. Biol Bull 165: 343-352.

BARRAdAs JI, AmARAL FD, HERnÁNDEZ MIM, FloresMONTES MJ AND STEINER AQ. 2010. Spatial distribution of benthic macroorganisms on reef flats at Porto de Galinhas Beach (northeastern Brazil), with special focus on corals and calcified hydroids. Rev Biotemas 23: 2 .

BASTIDAS C AND BONE D. 1996. Competitive strategies between Palythoa caribaeorum and Zoanthus sociatus (Cnidaria: Anthozoa) at a Reef Flat environment in Venezuela. B Mar Sci 59: 543-555.

BIRKELAND C. 1997. Life and death of Coral Reefs, New York: Chapman and Hall, 536 p.

BRAZEAU DA AND LASKER HR. 1992. Growth rates and growth strategy in a clonal marine invertebrate, the Caribbean Octocoral Briareum asbestinum. Biol Bull 183: 269-277.

BROWN PJ AND TAYLOR RB. 1999. Effects of trampling by humans on animals inhabiting coralline algal turf in the rocky intertidal. J Exp Mar Biol Ecol 235: 45-53.
BUDDEMEIER RW AND KINZIE RA. 1976. Coral growth. Oceanogr Mar Biol Ann Rev 14: 183-225.

BudDEMEIER RW AND SMITH SV. 1988. Coral reef growth in an era of rapidly rising sea level: predictions and suggestions for long-term research. Coral Reefs 7: 51-56.

CAstro CB, ECHEVERría CA, DE Oliveira PD AND FonseCA CG. 1999. Distribuição do bentos (Cnidaria e Echinodermata) em costões rochosos da Baía de Ilha Grande, Rio de Janeiro, Brasil. Oecol Bras 7: 8.

CONNELL JH. 1978. Diversity in tropical rain forests and coral reefs. Science 199(4335): 1302-1310.

COOKE WJ. 1976. Reproduction, growth, and some tolerances of Zoanthus pacificus and Palythoa vestitus in Kaneohe Bay, Hawaii. In: MACKIE GO (Ed), Coelenterate ecology and behavior, New York, Plenum Press, USA, p. 281-288.

Costa DL, Gomes PB, SANTOS AM, VALENÇA NS, VieIRA NA AND PÉREZ CD. 2011. Morphological plasticity in the reef zoanthid Palythoa caribaeorum as an adaptive strategy. Ann Zool Fenn 48: 349-358.

CRUZ ICS, KIKUCHI RKP, LONGO LL AND CREED JC. In press. Evidence of a phase shift to Epizoanthus gabrieli Carlgreen, 1951 (Order Zoanthidea) and loss of coral cover on reefs in the Southwest Atlantic. Marine Ecology. doi: $10.1111 /$ maec. 12141 .

Dight IJ AND SCHERL LM. 1997. The International Coral Reef Initiative (ICRI): Global priorities for the conservation and management of coral reefs and the need for partnerships. Coral Reefs 16: 139-147.

FADLALlaH YH, KARLSON RH AND SEBENS KP. 1984. A comparative study of sexual reproduction in three species of Panamanian zoanthids (Coelenterata: Anthozoa). Bull Mar Sci 35: 80-89.

FAUTIN DG. 1988. Anthozoan dominated benthic environments. In: Coral Reef Symposium, 6, Townsville. Proceeding of the $6^{\text {th }}$ International Coral Reef Symposium, Townsville, p. 231-236.

Floeter SR, Krohling W, Gasparini JL, Ferreira CEL AND ZALMON IR. 2007. Reef fish community structure on coastal islands of the southeastern Brazil: the influence of exposure and benthic cover. Environ Biol Fish 78:147-160.

FrancINI-FILHO RB ET AL. 2013. Dynamics of coral reef benthic assemblages of the Abrolhos Bank, Eastern Brazil: Inferences on natural and anthropogenic drivers. PLoS One 8: e54260.

GARRABOU J. 1999. Life-history traits of Alcyonium acaule and Parazoanthus axinellae (Cnidaria, Anthozoa), with emphasis on growth. Mar Ecol Prog Ser 178: 193-204.

HAWKINS JP AND RoBERTS CM. 1994. The growth of coastal tourism in the Red Sea: present and future effects on coral reefs. Ambio 23: 503-508.

HAYWICK DW AND MuELLER EM. 1997. Sediment retention in encrusting Palythoa spp. - a biological twist to a geological process. Coral Reefs 16: 39-46.

HILL T AND LEWICKI P. 2006. Statistics: methods and applications. A Comprehensive Reference for Science, Industry, and Data Mining, $1^{\text {st }}$ ed., Oklahoma: Statsoft, 833 p. 
HUGHES RN AND CANCINO JN. 1985. An ecological overview of cloning in metazoa. In: JACKSON JBC, BUSS LW AND COOK RE (Eds), Population biology and evolution of clonal organisms, New Haven and London: Yale University Press, London, UK, p. 153-186.

HUGHES TP AND JACKSON JBC. 1980. Do corals lie about their age? Some demographic consequences of partial mortality, fission and fusion. Science 209: 713-715.

Hughes TP AND JACKSON JBC. 1985. Population dynamics and life histories of foliaceous corals. Ecol Monogr 55: 141-166.

JACKSON JBC. 1977. Competition on marine hard substrata: the adaptive significance of solitary and colonial strategies. Am Nat 111: 743-768.

KARLSON RH. 1980. Alternative competitive strategies in a periodically disturbed habitat. B Mar Sci 30: 894-900.

KARLSON RH. 1983. Disturbance and monopolization of a spatial resource by Zoanthus sociatus (Coelenterata, Anthozoa). B Mar Sci 33: 118-131.

KARLSON RH. 1991. Fission and the dynamics of genets and ramets in clonal cnidarian populations. Hydrobiologia 216: $235-240$

LABOREL J. 1970. Madréporaries et hydrocoralliaries récifaux des cotes brésilienes. Systematique, écologie, répartition verticale et geographique. Résultats Scientifiques des Campagnes, "Calypso". Paris 9: 17-229.

LIDDLE MJ AND KAY AM. 1987. Resistance, survival and recovery of trampled coral of the Great Barrier Reef. Biol Cons 42: 1-18.

LOYA Y. 1972. Community structure and species diversity of a hermatypic coral at Eilat, Red Sea. Mar Biol 13: 100-123.

LOYA Y. 1978. Plotless and transect methods. In: STODDART DR AND JOHANES RF (Eds), Coral reefs: research methods, UNESCO: Monograph on Oceanographic Methodology Series, p. 197-2171.

MCCUllagh P AND Nelder JA. 1989. Generalized Linear Models, $2^{\text {nd }}$ ed., London: Chapman and Hall, 515 p.

MCFADDEN CS. 1986. Colony fission increases particle capture rates of a soft coral: Advantages of being a small colony. $\mathrm{J}$ Exp Mar Biol Ecol 103: 1-20.

Medeiros C, Macedo SJ, Feitosa FAN and Koening ML. 1999. Hydrography and phytoplankton biomass and abundance of North-East Brazilian waters. Arch Fish Mar Res 47: 133-151.

MendoÇA-Neto JP AND GAMA BAP. 2009. The native Palythoa caribaeorum overgrows on invasive species in the intertidal zone. Coral Reefs 28: 497.

Moberg F AND FolKE C. 1999. Ecological goods and services of coral reef ecosystems. Ecol Econ 29: 215- 233.
MuEller E AND HAYWICK W. 1995. Sediment assimilation and calcification by the Western Atlantic reef Zoanthid, Palythoa caribaeorum. Bull Inst Océanogr Monaco 14: 89-100.

NeIL D. 1990. Potential for coral stress due to sediment resuspension and deposition by reef walkers. Biol Cons 52: 221-227.

OIGMAN-PsZcZol SS, FigUEIREDO MAO AND CREED JC. 2004. Distribution of benthic communities on the tropical rocky subtidal of Armação dos Búzios, Southeastern Brazil. Mar Ecol 25: 173-190.

OSBORNE PL. 2000. Tropical ecosystems and ecological concepts, New York: Cambridge University Press, 464 p.

Rabelo EF, SoAres MO AND Matthews-Cascon H. 2013. Competitive interactions among zoanthids (Cnidaria: Zoanthidae) in an intertidal zone of northeastern Brazil. Braz J Oceanogr 61: 35-42.

RoDGERS KS AND COX EF. 2003. The effect of trampling on Hawaiian corals along a gradient of human use. Biol Cons 112: 383-389.

RYLAND JS AND WARNER GF. 1986. Growth and form in modular animals: ideas on the size and arrangement of zooids. Philos Trans R Soc Lond B 313: 53-76.

SARMENTO VC, BARRETO AFS AND SANTOS PJP. 2011. The response of meiofauna to human trampling on coral reefs. Sci Mar 75: 559-570.

SEBENS KP. 1982. Intertidal distribution of zoanthids on the Caribbean coast of Panama: effects of predation and desiccation. B Mar Sci 32: 316-335.

STONER DS. 1989. Fragmentation: a mechanism for the stimulation of genet growth rates in an encrusting colonial ascidian. Bull Mar Sci 45: 277-287.

SUCHANEK TH AND GREEN DJ. 1981. Interspecific competition between Palythoa caribaeorum and other sessile invertebrates on St. Croix reefs, U.S. Virgin Islands. In: Coral Reef Symposium, 4, Manila. Proceeding of the $4^{\text {th }}$ International Coral Reef Symposium, Manila, p. 679-684.

TANNER JE. 1999. The effects of density on the Zoanthid Palythoa caesia. J Anim Ecol 66: 793-810.

Tubaro A, Durando P, Del FaVEro G, ANSAldi F, ICARdi G DEEDS JR AND SosA S. 2011. Case definitions for human poisonings postulated to palytoxins exposure. Toxicon 57 : 478-495.

TURON X AND BECERRO MA. 1992. Growth and survival of several ascidian species from the northwestern Mediterranean. Mar Ecol Prog Ser 82: 235-247. 